\title{
Philippines: \\ In Search for Self-Determination. The Political History and Armed Struggle of the Moro National Liberation Front in Mindanao
}

\author{
Imma Concepcion F. GALERIANA \\ Primitivo III C. RAGANDANG
} \begin{abstract}
marshals and zone commanders at the municipality level. Several attempts were done in order to halt the skirmishes led by the MNLF. Regardless of the countless skirmishes, assaults and uprisings, the MNLF sees this peaceful way now as a highly possible solution to end the Bangsamoro identity struggle against marginalization, oppression and fight for self-determination.
\end{abstract}

Abstract. The myriad of Moro insurgent movements in the Philippines could be traced back to the abhorrent memoirs of Spanish occupation. The contemporary armed conflict between the government in Manila and the Moros was highly triggered by the Jabidah massacre in March 1968. The globally-known day of infamy inspired the historical birth of the Moro National Liberation Front (MNLF) to start launching the freedom struggle of the oppressed Bangsamoro people of Mindanao against Philippine colonialism under the regime of Dictator Ferdinand E. Marcos. The MNLF was formally organized into two parallel structures: one political, the other military. The political wing was composed of a central committee, various bureaus and a system of provincial and village committees. The military wing - the Bangsa Moro Army - had an overall field marshal, provincial field

Keywords: insurgent, MNLF, Bangsamoro, Tripoli, Jeddah Accord, Bangsamoro Basic Law

\section{Introduction}

The myriad of Moro insurgent movements in the Philippines could be traced back to the abhorrent memoirs of Spanish occupation. Resistance to colonization was espe-
Imma Concepcion F. GALERIANA

Political Science Department, Mindanao State University-lligan Institute of Technology Iligan City, Lanao del Norte, Philippines

Primitivo III C. RAGANDANG

Political Science Department, Mindanao State University-lligan Institute of Technology Iligan City, Lanao del Norte, Philippines

E-mail: prime.tivo@gmail.com

Conflict Studies Quarterly

Issue 24, July 2018, pp. 12-25

DOI:10.24193/csq.24.2

Published First Online: 05/07/2018 
cially strong among the Moro population of Southwestern Mindanao. Consequently, several secessionist groups and movements were formed.

When the Republic of the Philippines formally achieved its independence from the U.S. on July 4,1946, a series of land resettlement programs in Mindanao took place (in the 1950s and 1960s) to ease the social unrest spawned by the Communist-led Huk rebellion in the islands of Luzon and the Visayas and, supposedly, to further develop Mindanao by exploiting its vast natural resources. The Moros became exceedingly distressed by the influx of Christians from the North who did not only threaten their economic and political survival, but also compromised their culture and identity, since they were making Moros a minority as well. Unavoidably, these created grievances and dissatisfaction which, at a point in time, fuelled the neo-Moro rebellion.

The contemporary armed conflict between the government in Manila and the Moros was highly triggered by the Jabidah massacre in March 1968, under the Marcos administration. This led to the establishment of the first Moro separatist groups initially with the founding of the Moro Independence Movement (MIM) and eventually the Moro National Liberation Front (MNLF) led by University of the Philippines Professor Nurullaji "Nur" Misuari, who became its chairman. Thus, began an organized and sustained Moro insurgency.

The MNLF eventually gained support from Muslim countries, Libya and Malaysia, with its struggle for an independent Moro nation. But on the year 1976, an intervention by the Organization of Islamic Conference (OIC)ensued, which made the MNLF sign the Tripoli agreement with the Marcos administration to end hostilities in exchange for the government working to grant greater autonomy in Muslim-populated areas.

However, Misuari's deputy, Salamat Hashim, leads a group of key commanders in splitting from the MNLF. They were disappointed with Misuari's compromise and vowed to continue fighting by stressing not only a nationalist but also an Islamic agenda. Hashim formally broke away from the MNLF and created the MILF on 30 ${ }^{\text {th }}$ of December 1977.

\section{Research Objectives}

To recollect and assess the political history of the Moro National Liberation Front in Southern Philippines.

\section{Discussions and Analysis}

As opposed to today's dreadful experiences of the Bangsamoro fighting for the right to self-determination and for the passage of the Bangsamoro Basic Law, before the Spanish colonization, the Moros have already settled in the lands of what we now politically address as Mindanao and Sabah.Despite the ability of the Muslims to thwart successive attempts of the Spanish colonial forces to subjugate them, it provides such 
utter wonder how they lost their lands even during the succeeding colonization of the Americans up until the Philippine independence. They were continuously discriminated and separated from the Northern inhabitants of the Philippine archipelago, most of whom were conquered and became Christian converts. This has caused profound cynicism as the colonizers were successful in cultivating a culture of suspicion and terror among converted Christians against their Muslim brothers, in order to keep a hold of control over the Mindanao land and its people.

During President Diosdado Macapagal's administration, he formally put forth the Sabah Claim in 1962, based on the sovereignty once exercised by the Sulu sultanate over the northern Borneo territory. By all indications, however, President Macapagal used a nonviolent, diplomatic approach to win Sabah. But when the late Ferdinand Marcos defeated President Diosdado Macapagal on his attempt during the 1965 presidential elections, Marcos did pursue Sabah but contrary to the diplomatic attempts Macapagal conducted. By the time Malaysia had reclaimed independence from the British rulers, they were able to colonize Sabah by rental and eventually annexed it in the 1960s. Malaysia seemed an easy and vulnerable target at that time. The Federation was still new and fragile, having come into being only in 1963. Ferdinand Marcos cast his avaricious eyes on a country that was still on its way to political cohesion their fragility as a newly independent state was seen by Marcos and the Philippine military associated with him as a weakness. They, therefore, apprehended a plot in 1967 called the "Operation Merdeka" as a force of troops to weaken Sabah.

Operation Merdeka was led by Maj. Eduardo Abdul Latif Martelino as operations officer. In order for the infiltration of Sabah to be a success, the plan involved the employing of nearly 200 Tausug and Sama Muslims aged 18 to 30 from Sulu and Tawi-Tawi. They were to be trained in the island-town of Simunul. What enticed these young men to join the training was not only because they were promised of a monthly allowance but also over the vision of eventually becoming a member of an elite unit in the Philippine Armed Forces. The name of the commando unit was Jabidah.

\section{The Triggers}

\section{Jabidah Massacre}

The Jabidah massacre was considered by many as the founding moment of Muslim separatism in Mindanao, which took place on the rocky island of Corregidor that involved the killing of 64 Moro trainees who were planning to leave the training due to several reasons. The trainees complained and secretly wrote a petition addressed to President Marcos, signed by about 62 trainees. Others placed their thumb marks. They wanted their pay plus an improvement in their living conditions. Martelino visited the trainees and assured them of their pay. He later met with the 4 leaders of the petitioning group. These reasons were revealed by the only survivor of the cold-blooded massacre, named 
Jibin Arula. When they eventually discovered that the training's purpose was to intrude and attack the Malaysians, they refused to continue the training. As Jibin expressed, "How could we attack the Malaysians when they are our brothers and we do not have any quarrel with them?". The recruits then necessitated to be returned home. For the military planners, it seemed that there was only one choice.

The horrible bloodshed was revealed by thelate Senator Benigno "Ninoy" Aquino, Jr. in his privileged speech in the Senate floor. He was accused of an act of treason on since he put the national security of the country at risk, at that time. This revelation, however, did not only anger the Malaysians including Sabah Chief Minister DatuTun Mustapha Haron, but shook the Moros and their leaders, particularly Cotabato Gov. Datu Udtog Matalam. Hardly two months after the incident, Datu Udtog Matalam headed the move to create an Islamic Republic of Mindanao in answer to the alleged systematic policy of genocide, discrimination, and dispossession of lands pursued forcefully by the government. On May 1, 1968, he organized the Muslim (and later Mindanao) Independence Movement (MIM), which sought to form a state comprising of the contiguous southern portion of the Philippine Archipelago.

\section{The Birth}

The globally-known day of infamy inspired the historical birth of the Moro National Liberation Front (MNLF) to start launching the freedom struggle of the oppressed Bangsamoro people of Mindanao against Philippine colonialism under the murderous regime of Dictator Ferdinand E. Marcos. The MNLF was conceptualized and organized by Abul Khayr Alonto and Jallaludin Santos who were at that time active with the BangsaMoro Movement. With Muslim congressmen and leaders as advisers, they recruited young Muslims from different tribes. Jallaludin Santos suggested to Abul Khayr that they could benefit from the vibrancy of Nur Misuari, professor at University of Philippines, who was with the leftist movement Kabataang Makabayan. Abul Khayr persuaded Nur to join the movement. Advisers and members wanted Abul Khayr to chair the MNLF, but he declined and indicated that Misuari could have the position. As he saw it, the work of the Chairman would be to solicit help from Muslim countries and negotiate their involvement in creating a solid solution for the BangsaMoro problem. Abul Khayr on the other hand, out of loyalty to his men could not bear to travel and leave his brothers in battle. Accordingly, Misuari became the Chairman though not the founder or leader.

Later in March 1968, the Moro students in Manila held a week-long protest in front of the presidential palace. Believing that several dozens of Moro army recruits had been murdered, the students displayed an empty coffin which symbolized oppression and the government's low regard for its Muslim citizenry. They interpreted the tragedy as incontrovertible proof that the problems in Mindanao could no longer be solved within 
the ambit of the Republic of the Philippines, and that a new nation-state had to be born. As Misuari himself recalled, it was during those nightly vigils that his political career, coinciding closely with the secessionist aspirations of the Moro Nationalist Liberation Front (MNLF), germinated (George, 1980).In one interview with Misuari, he reminisced about how the Jabidah Massacre stood at the crest of centuries of Muslim struggle for self-determination and justice which justified the creation of the MNLF. For the Jabidah Massacre could only be remembered within the frame of conflict between Muslims and non-Muslims that has persisted for many generations.

By the end of 1972, the emerging Muslim revolution began to coalesce under the MNLF's banner. The MNLF never controlled all the insurgents fighting the government and was, in fact, a loosely knit group, with the borders between those fighters who were members of, aligned with, or exterior to the MNLF never very clear. Nevertheless, the MNLF was the principal, and by far the most important, armed separatist organization, largely because it became the major supplier of arms and ideological support for the insurgency. One of the reasons for the loosely knit character of the MNLF was the fact that virtually its entire core leadership was, by 1973, operating from outside the country, far from local commanders. Nur Misuari, with a large reward offered for his capture, escaped from Manila to the South after martial law was declared, from there to Sabah, then on to Libya (George, 1980).

The MNLF was formally organized into two parallel structures: one political, the other military. The political wing was composed of a central committee, various bureaus, and a system of provincial and village committees. The military wing - the Bangsa Moro Army - had an overall field marshal, provincial field marshals and zone commanders at the municipality level. The chairman of the central committee, almost all of whose members were in Tripoli by 1974, was Nur Misuari (Dacanay, 2013). The vice-chairman, by 1974, was Hashim Salamat. In his 1977 interview, Salamat states that he and his cohorts were forced underground when, immediately after martial law, Datu Udtug signed an "affidavit" against them and turned it over to the Philippine. A short while later, his group joined forces with Nur Misuari and Salamat then made his way to Tripoli. Abulkhayr Alonto, member of a prominent Maranao family, was overall field commander of the Bangsa Moro Army and one of the few top leaders to remain in the Philippines. Although all estimates remain only rough guesses, the MNLF probably came to have between ten thousand and thirty thousand men in its military branch.The authority over rebel fighters enjoyed by the MNLF derived at least partly from its access to critical resources, particularly weapons, from outside the Philippines. Before the removal from power of Tun Mustapha in late 1975, the primary conduit of weapons was by boat from Sabah. The weapons arrived in Sabah from Libya and other Muslim nations. The MNLF also controlled political and military training, propaganda, and diplomatic contacts with Muslim, primarily Arab, states. 


\section{The Conflict Phases and Peace Agreements}

\section{$1^{\text {st }}$ Conflict Phase}

(October 24, 1972-December 24, 1976)

On October 24,1972, the MNLF began its rebellion against the government and consulted such matters to the Organization of the Islamic Conference (OIC). On December of 1972, Datu Udtog Matalam surrendered to government troops and on March 21, 1973 it resulted to the deaths of some 20 rebels. OIC foreign ministers appealed to the government to end its repression of Muslims in the southern provinces of the Philippines and established a five-member conciliation commission (Afghanistan, Libya, Saudi Arabia, Senegal, Somalia) on March 27, 1973. But the skirmishes went on as the government troops and MNLF rebels clashed in the Zamboanga peninsula on July 14-21, 1973, resulting in the deaths of some 350 rebels and 25 government soldiers. The OIC conciliation commission issued a report at the OIC summit meeting in Lahore, Pakistan in February 1974.

On June 25, 1974, OIC foreign ministers appealed once again to the government to end military operations against the MNLF and to negotiate with MNLF representatives. But there was no progress in this as the government troops captured UPI from MNLF rebels on August 1, 1974, resulting in the deaths of some 20 rebels. Another clash happened on Sacol island on $1^{\text {st }}$ of September 1974, resulting in the deaths of some 40 rebels. OIC Secretary-General Hassan Tohamy attempted to mediate negotiations between government and MNLF representatives from December 1974 to June 1975. Muslim rebels killed 41 government soldiers on Jolo island on January15, 1975.

The OIC facilitated negotiations between government and MNLF representatives in Jeddah, Saudi Arabia beginning on January 28, 1975 but the government broke off negotiations with the MNLF on February3, 1975. President Marcos ordered a ceasefire in the southern provinces of the Philippines on February 10,1975 but still the Muslim rebels killed 32 civilians in Lanao del Sur province on August 8, 1975 and another clash aroused on August 9, 1975, resulting in the deaths of 69 rebels and six government troops. President Marcos proposed, once again, a peace plan on August 14, 1975, but the MNLF rejected theproposal on September 11,1975. Though the OIC foreign ministers appealed for a ceasefire and peaceful negotiations between the government and the MNLF on May 15, 1976, the Muslim rebels attacked a school on Mindanao island on the following month, resulting in the deaths of seven children.

On December 15-23, 1976, an OIC conciliation commission mediated negotiations between government and MNLF representatives in Tripoli, Libya. The parties then agreed to a cessation of military hostilities, and the ceasefire went into effect on December 24, 1976. The agreement also provided for autonomy for 13 provinces and nine cities in 
Mindanao and Sulu (this part of the agreement was never implemented). Some 50,000 individuals were killed during the conflict and some 500,000 individuals were displaced during the conflict.

\section{The Tripoli Agreement}

The first phase of the Government and MNLF conflicted ended when representatives from both parties negotiated in Tripoli from February 7 to March 3, 1977, and the government agreed to grant autonomy to the southern provinces on March 20,1977. On March 25, 1977, President Marcos issued a proclamation establishing an autonomous region in the southern Philippines. The government conducted a referendum concerning autonomy for the southern provinces on April 17, 1977, but the referendum was boycotted by the MNLF. Some 98 percent of the voters rejected autonomy for the southern provinces in the referendum.

OIC Secretary-General Ahmadu karim Gaye and Foreign Minister Ali Abdusalam Trieki of Libya mediated negotiations between government and MNLF representatives in Manila on April 20-21,1977. The OIC foreign ministers expressed support for the MNLF (by extending the MNLF observer status in the OIC) on May 22, 1977.

\section{$2^{\text {nd }}$ Conflict Phase}

(September 17, 1977-September 5, 1986)

Government troops and Muslim rebels clashed on Basilan and Jolo islands on September 17-21, 1977, resulting in the deaths of 86 individuals. Government troops and Muslim rebels clashed on Basilan island on October 2-8, 1977, resulting in the deaths of 53individuals. Government troops and Muslim rebels clashed in the town of Danag on Jolo island on October10,1977, resulting in the deaths of 33 government soldiers. Government troops and Muslim rebels clashed on Mindanao, Jolo and Basilan islands on October 12-26, 1977, resulting in the deaths of some 50 government soldiers. Government troops and Muslim rebels clashed on Basilan island on April 30, 1978, resulting in the deaths of some 80 rebels and 11 government soldiers.

Elections for representatives to two legislative assemblies were held in April and May 1979. President Marcos lifted martial law on January 17, 1981. Government troops and Muslim rebels clashed in Lanao del Sur province on March 11, 1982, resulting in the deaths of 25 individuals.

Some 200,000 Muslims fled as refugees to Sabah, Malaysia between 1968 and 1983. Government and MNLF representatives resumed negotiations in Manila on March 13, 1986. President Corazon Aquino and MNLF representatives signed a ceasefire agreement on September 5, 1986.Some 35,000 individuals were killed, and some 900,000 individuals were displaced during the conflict. 


\section{The Jeddah Accord}

Corazon Aquino succeeded Marcos from 1986-1992 and resumed talks with the MNLF, producing the Jeddah Accord in 1987, in attempt to further discussions on a democratic process for Mindanao. The two panels met in the evening of January 3, 1987 at the Headquarters of the Organization of Islamic Conference in Jeddah, Kingdom of Saudi Arabia and agreed to:

1. Create a Joint Commission which will discuss and draft the mechanism and details of the proposal for the grant of full autonomy to Mindanao, Basilan, Sulu, Tawi-Tawi and Palawan subject to democratic processes. The Joint Commission shall be composed of three members from each panel and shall initially meet in Manila on February 9, 1987. It shall endeavour to complete its work within 90 days from said date;

2. Create provincial committees to monitor and implement the observance of the agreement on the cessation of hostilities between the Philippine government and the MNLF;

3. Propose the immediate formulation and implementation of a comprehensive economic and social development program in priority areas mutually agreed upon.

This was then ultimately restricted by the 1987 Constitution that was passed as part of the democratic reconfiguring of the Philippines post-Marcos. Article X, Sections 15-21 of the 1987 Constitution established regional restrictions, furthered by RA 6734, in August, 1989, providing an Organic Act for the Autonomous Region in Muslim Mindanao (ARMM) following a plebiscite (Abubakar, 2004). The MNLF rejected the Organic Act, as well as the plebiscite-formulated ARMM, and negotiations were halted until1992 (Mackerras, 2003).

\section{$3^{\text {rd }}$ Conflict Phase}

(February 1, 1988-November 7, 1993) ${ }^{5}$

The MNLF resumed its rebellion against the government on February 1, 1988. A referendum was held on Mindanao and Sulu islands on November 19, 1989, resulting in the approval of a plan providing for regional autonomy of the Moro provinces. The MNLF called upon Muslims to boycott the referendum. A six-member OIC conciliation commission (Indonesia, Libya, Saudi Arabia, Bangladesh, Senegal, and Somalia) chaired by Ali Alatas, Indonesian Minister of Foreign Affairs, mediated negotiations between government and MNLF representatives from October 25, 1993 and August 29, 1996. Government and MNLF representatives signed a cease fire agreement in Jakarta, Indonesia on November 7, 1993.

\section{Final Peace Agreement of $1996^{6}$}

In 1992, the new presidency led to a change in administration priorities and the Ramos Period resumed peace negotiations (Abubakar, 2004). After four years of an interim 
ceasefire and exploratory talks, in 1996, the Final Agreement on the Implementation of the 1976 Tripoli Agreement was signed between the Philippine Government and the MNLF) (MILF Peace Panel/Asia Foundation, 2010). The 1996 Agreement was intended as a two-stage process, with Phase I composing a 3-year transition period to join MNLF elements with the Armed Forces of the Philippine (AFP) and to undergo intensive socio-economic rehabilitation in the region, and Phase II consisting of the devolution of powers and the repeal of the Organic Act (RA 6734). While this was satisfactory for the MNLF, the MILF continued armed resistance, reaffirming their commitment to the establishment of a self-determining Bangsamoro territory (Mackerras, 2003).

Government and MNLF representatives signed an agreement in Manila on September 2, 1996, which provided for the establishment of the Autonomous Region of Muslim Mindanao (ARMM). Nur Misuari was appointed as governor of the ARMM. The OIC established the OIC Monitoring Team (OIC-MT) to monitor the peace agreement beginning on September 2,1996. The OIC sent a fact-finding mission to southern Philippines on October 16-23, 2000. The World Bank (WB) and Japan provided reconstruction assistance in the ARMM beginning in 2002. The OIC-MT disbanded on April 2, 2002. The OIC sent a fact-finding mission to southern Philippines on May 18-21, 2006.

The OIC established the eleven-member Peace Committee for Southern Philippines (PCSP) consisting of representatives from Indonesia, Saudi Arabia, Libya, Somalia, Senegal, Bangladesh, Malaysia, Brunei, Egypt, Turkey, and Pakistan. The 1st session of the tripartite meeting of representatives of the Philippines government, MNLF, and OIC/PCSP met in Jeddah, Saudi Arabia on November 10-12, 2007.

The $2^{\text {nd }}$ session of the tripartite meeting of representatives of the Philippines government, MNLF, and OIC/PCSP met in Istanbul, Turkey on February 14-16, 2008. The 3rd session of the tripartite meeting of representatives of the Philippines government, MNLF and OIC/PCSP met in Pasay City, Philippines on March 11-13, 2009.The 4th session of the tripartite meeting of representatives of the Philippines government, MNLF, and OIC/PCSP met in Jeddah, Saudi Arabia on February 22-23, 2011. The 5th session of the tripartite meeting of representatives of the Philippines government, MNLF, and OIC/ PCSP convened in Bandung, Indonesia on March 1, 2012, but the MNLF unilaterally suspended its participation in peace negotiations with the Philippines government on March 2, 2012. The two sides disagreed over the issue of revenue-sharing from mineral extraction in the ARMM area. On February 7, 2013, the Organization of the Islamic Conference (OIC) appealed to the Philippines government and MNLF to negotiate a resolution of the remaining issues.

\section{The Revolutionary Founder}

The drive and aspiration of revolutionaries is their vision. In the case of Chairman Nur Misuari of the Moro National Liberation Front (MNLF), he seeks for Mindanao's liber- 
ation. Chairman Nur is a Tausug, the Mindanao tribe that rules the provinces of Sulu, Tawi-Tawi and Basilan - all island-provinces in Southern Mindanao. He was a Political Science professor at the University of Philippines when he became a revolutionary and he was at the age of 27 when he established the Mindanao Independence Movement, which eventually became the Moro National Liberation Front (MNLF) in Malaysia in of year 1969. 'Without justice, there can never be an end to the war in Mindanao' - Nur Misuari.

In the early 60s, the heirs of a Sultan from Sulu who owned Sabah transferred the right to claim the territory to the Philippine government. The Sultan of Brunei ceded North Borneo (Sabah) to the Sultan of Sulu who helped quell a rebellion there in the early 17th century. Because of the MNLF, the Philippine government did not actively claim Sabah.

Misuari was 34 when he forged a pro-autonomy peace settlement with the Philippine government in Libya in 1976. In 1996, he led the MNLF in signing a pro-autonomy peace settlement with the Philippine government. He became governor of the Autonomous Region in Muslim Mindanao (ARMM) which was established through a referendum for autonomy in 1989. The agreement resulted in another referendum for autonomy in 2001.From 1996 to 2001, he was accused of mismanagement as ARMM governor, and his allies ousted him as MNLF head, resulting in a three-faction group, a division which holds up to now. In 2001, he resorted to an armed struggle because he could not get the support of former president Gloria Arroyo for his second bid to head the ARMM. He fled to Malaysia where he was arrested and brought back to Manila. He served time at a police headquarters in southern Luzon until 2008. Charges of sedition and rebellion against him were withdrawn.

Although Misuari was deposed in 2000 by his senior officials headed by his Foreign Affairs chief Parouk Hussin - who along with veteran rebel leaders headed by Muslimen Sema, the front's secretary general - who made up the so-called Council of 15.Hussin, who eventually became governor of the Muslim autonomous region, was also deposed several years later after the Council of 15, disgruntled at his leadership, put back Misuari as head of the MNLF in 2007. But Sema and majority of the MNLF leaders ousted Misuari again in 2008 for lack of trust and confidence. Sema's group previously appointed Misuari as chairman emeritus, but he rejected the position and insisted he is the sole chairman of the MNLF. Sema has not issued any public statement about Alonto's declaration. In November 2001, on the eve of the elections in the Muslim autonomous region, Misuari accused the government of reneging on the peace agreement, and launched a new rebellion in Sulu and Zamboanga City, where more than 100 people were killed.

Misuari then escaped by boat to Malaysia, where he had been arrested and deported to the Philippines where he was jailed and eventually released by then President Gloria Arroyo in exchange for his support to her election bid and her allies in the Senate and Congress in 2004.But Misuari's fall had severely affected the MNLF which is now 
heavily divided and rift among its leaders is becoming more apparent. Misuari also ran thrice for governor in Sulu province even while under detention but lost. On September 2013, Misuari's group again launched deadly attacks in Zamboanga City that sparked three weeks of deadly street battles that killed and wounded over 400 people, and left over 130,000 without homes following the burning of several Muslim villages. Misuari remains in hiding following the attacks.

\section{On the Bangsamoro Basic Law (BBL)}

The Bangsamoro, according to the proposed draft of the Bangsamoro Basic Law, are those who at the time of conquest and colonization were considered natives or original inhabitants of Mindanao and the Sulu archipelago and its adjacent islands including Palawan, and their descendants, whether of mixed or of full blood, shall have the right to identify themselves as Bangsamoro by ascription or self-ascription. Spouses and their descendants are classified as Bangsamoro. The purpose of this Basic Law is to establish a political entity, provide for its basic structure of government in recognition of the justness and legitimacy of the cause of the Bangsamoro people and their aspiration to chart their political future through a democratic process that will secure their identity and posterity and allow for meaningful self-governance.

There were several allegations that the MNLF is not supportive of the BBL; since it was based on the peace agreement signed by the government with another Moro group, the Moro Islamic Liberation Front (MILF), which broke away from the MNLF in the late 1970s. But weeks after Abul Kayr Alonto declared himself new chieftain of the Moro National Liberation Front in 2014, he has publicly thrown his support to the peace process between Manila and the Moro Islamic Liberation Front, which has been fighting for decades for self-determination in the restive southern region of the Philippines. Alonto, who was among the original founding members of the MNLF, also urged Muslims to support the Bangsamoro agreement between the Aquino government and the MILF, the country's largest Muslim rebel group. "The Moro people want to set their house in order but how can they set their house in order when the very key to their own hands is not in their own hands. And the sad part is that the people who want to govern them do not even speak the language that the people to be governed speak. Ito na po ang key and I believe the taught by my grandfather was saying that the key is not in their hands, the key now is the framework basic law that we look forward to that will be approved by Congress or through Constitutional amendment, please do so, let's do it so that we can unite and spare the future generation of a war of aggression", Alonto said.

Randolph Parcasio's 40-minute talk during the Regional Forum on Peace and Security held in Zamboanga last September 2013, disclosed that the MNLF maintains its position. It will allow Congress to decide on the proposal to create a new Bangsamoro political and geographic entity that will replace the Autonomous Region in Muslim Mindanao 
(ARMM). "The MNLF is not opposed to the BBL, because the official position of the MNLF is let the legislature take its natural course", Mr. Parcasio reiterated. He also disclosed the status and efforts of the Organization of Islamic Cooperation (OIC) in reuniting the MNLF and MILF since their unification is a critical to the success of the BBL. The MILF broke away from the MNLF after disagreements over ideological issues following the Tripoli Agreement, which the OIC brokered in 1976.

Then and now, the MNLF under Mr. Misuari wants to establish a secularist "Bangsamoro Republik" while the MILF was aiming for an Islamic state, according to MNLF commander Amilpasa Bandaring. In a statement issued by the OIC, "We urge the leaders of both the MNLF and the MILF to consolidate their coordination and cooperation through the Bangsamoro Coordination Forum (BCF) and to engage other stakeholders in order to close ranks and strengthen and consolidate their cooperation and unity and maintain their peaceful struggle for the common cause".

On year 2015, the two disputing Muslim rebel groups - the Moro Islamic Liberation Front (MILF) and a bloc of the Moro National Liberation Front (MNLF) - declared their unity as they hard-pressed for the passage of the proposed Bangsamoro Basic Law (BBL). "For the sake of a just and dignified peace and of the general welfare of the people, we, the MILF and MNLF, firmly and solemnly declare a diluted Bangsamoro Basic Law, which is inimical to the full and faithful implementation of both the Comprehensive Agreement on the Bangsamoro and the 1996 Final Peace Agreement, is unacceptable to us and the Bangsamoro people", MILF chair Murad Ebrahim and Muslimin Sema, chair of the MNLF Council of 15, said in a joint statement following a meeting at Camp Darapanan in Sultan Kudarat, Maguindanao. Murad said the union was the product of the Bangsamoro Coordination Forum in Kuwait, which was called by the Organization of the Islamic Conference in May 2015.

\section{Conclusion}

The beginnings of the Moro struggle could be dated back as far as the Spanish Colonization of the Philippines during the 1950s.

Despite countless successful attempts of blocking foreigners from entering their turf, the Moros were grabbed of their own lands to give room to those "settlers" coming from the North. On one hand, what other grievances the Moros experienced were being highly minoritized, discriminated and oppressed in their own soil. The settlers, on the other hand, continuously felt indifferent, scared and apprehensive towards the Moros.

The Moro National Liberation Front (MNLF) was officially formed in 1969 to resist intensifying discrimination and marginalization, and in 1972 began an armed resistance in order to establish a self-determining Moro identity in Bangsamoro (Indonesian for 'Muslim Nation') which would be established within the territorial provinces and pen- 
insular regions of Mindanao, Sulu and Palawan. Its creation was greatly pushed when the Jabidah Massacre hit the headlines. This globally-known day of notoriety intensified the already existing protests of the Moros and stirred them enough to finally launch a formal struggle against the Government of the Republic of the Philippines. The Moros saw the tragedy as an irrefutable proof that the problems in Mindanao could no longer be solved within the ambit of the GRP, and that a new nation-state had to be born. For Nur Misuari, the once University of the Philippines professor who chaired the MNLF since its creation, "Without justice, there can never be an end to the war in Mindanao."

There were three (3) major conflict phases of the MNLF struggle. By the time each phase has concluded, a peace agreement was born. Hence, the Tripoli Agreement, Jeddah Accord and the 1996 Final Peace Agreement were ensued. There was one major intervenor, the Organization for Islamic Conference, who countless time appealed to the GRP for mediations, for ceasefire and for negotiations for the crafting of peace agreements.

The creation of the Bangsamoro Basic Law was a necessity for the MNLF, since it will be the legitimizing factor of the 1996 Final Peace Agreement. As what the new chairman of the MNLF said, "the key (to peace) now is the framework (of the) basic law that we look forward to that will be approved by Congress or through Constitutional amendment, please do so, let's do it so that we can unite and spare the future generation of a war of aggression." Regardless of the countless skirmishes, assaults and uprisings, the MNLF sees this peaceful way now as a highly possible solution to end the Bangsamoro identity struggle against marginalization, oppression and fight for self-determination.

\section{Recommendations}

The study on the political history of the MNLF could be more deepened if the following will be considered:

1. Future researchers are encouraged to delve more into the personal life of Nur Misuari. A good reading could be the book by Dr. Tom Stern entitled "Nur Misuari: An Authorized Biography".

2. A conduct of interview and FGD with the MNLF past and present members should be necessitated to further validate the past researches conducted.

3. A personal interview with the founding members and Nur Misuari himself would be an asset to a study about the MNLF.

4. The three major conflict phases should have three separate researches so important details in between would not be missed out.

5. A perception study should be conducted for the Bangsamoro on how they appreciate, view and perceive the MNLF as a group. 


\section{References}

1. Abubakar, C. A. (2004). Review of the Mindanao peace processes. Inter-Asia Cultural Studies, 5(3), 450-464. DOI: 10.1080/1464937042000288732.

2. Dacanay, B. (2013, September 15). The rise and fall of Nur Misuari. An Article. Gulf News Philippines. Retrieved from https://gulfnews.com/news/asia/philippines/therise-and-fall-of-nur-misuari-1.1231406.

3. George, T. (1980). Revolt in Mindanao: the rise of Islam in Philippine politics. Kuala Lumpur: Oxford University Press.

4. Mackerras, C. (2003). Ethnicity in Asia. New York: Routledge.

5. MILF Peace Panel/Asia Foundation. (2010). GRP-MILF peace process: compilation of signed agreements \& other related documents (1997-2010). Mindanao and San Francisco: MILF Peace Panel/Asia Foundation. 